Supporting Information

\title{
Synthetic Studies Toward the Guanacastepenes
}

\author{
Chambers C. Hughes, Joshua J. Kennedy-Smith, and Dirk Trauner \\ Center for New Directions in Organic Synthesis, Department of Chemistry, University of California-Berkeley, \\ Berkeley, California 94720
}

General: Tetrahydrofuran (THF) was distilled from Na/benzoquinone, triethylamine $\left(\mathrm{Et}_{3} \mathrm{~N}\right)$ was distilled from $\mathrm{CaH}_{2}$, and dichloromethane $\left(\mathrm{CH}_{2} \mathrm{Cl}_{2}\right)$ and ether $\left(\mathrm{Et}_{2} \mathrm{O}\right)$ were dried by passing through a column of activated alumina prior to use. $n$-Butyllithium ( $n$-BuLi) was titrated periodically with diphenylacetic acid. All other starting materials and solvents are commercially available and were used without further purification. Chromatography was carried out with ICN SiliTech 32-63 D 60 Å silica gel. Reactions and chromatography fractions were analyzed with Merck silica gel $60 \mathrm{~F}_{254}$ plates. Extracts were dried over $\mathrm{MgSO}_{4}$, and solvents were removed with a rotary evaporator at aspirator pressure. Unless otherwise noted, ${ }^{1} \mathrm{H}$ and ${ }^{13} \mathrm{C}$ NMR spectra were recorded in $\mathrm{CDCl}_{3}(7.27 \mathrm{ppm})$ on a Bruker AVB $400 \mathrm{MHz}$ spectrometer.

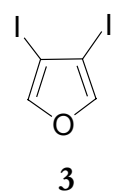

Large-scale preparation: To a $5 \mathrm{~L}$ three-neck flask fitted with a mechanical stirrer, a water cooled condenser, and a $100 \mathrm{~mL}$ dropping funnel was added 2,3-diiodo-2-butene-1,4-diol (100 g, $294 \mathrm{mmol}$ ), NMP $(1.25 \mathrm{~L})$, and hexanes $(2 \mathrm{~L})$. The mixture was stirred vigorously at $85{ }^{\circ} \mathrm{C}$. To this solution was added a preheated $\left(85^{\circ} \mathrm{C}\right)$ solution of $\mathrm{K}_{2} \mathrm{Cr}_{2} \mathrm{O}_{7}(86.5 \mathrm{~g}, 294 \mathrm{mmol})$ in $\mathrm{H}_{2} \mathrm{SO}_{4}(3 \mathrm{M}, 365 \mathrm{~mL})$ dropwise in portions $(60 \mathrm{~mL})$ over $2 \mathrm{~h}$. The biphasic mixture was stirred at $85^{\circ} \mathrm{C}$ for $5 \mathrm{~h}$ and then allowed to cool to rt. The hexane layer was decanted, and the remaining solvent was extracted once with hexanes (1 L). The hexane layers were combined, washed successively with water $(2 \times 500 \mathrm{~mL})$, a saturated $\mathrm{Na}_{2} \mathrm{~S}_{2} \mathrm{O}_{3}$ solution $(500 \mathrm{~mL})$, and brine $(500 \mathrm{~mL})$, dried, passed over a short plug of silica gel, and concentrated to yield 3 (10-20 g, 10-20\%) as a pale yellow liquid: ${ }^{1} \mathrm{H}$ NMR (300 MHz): $\delta 7.45$ (s, 2H). 


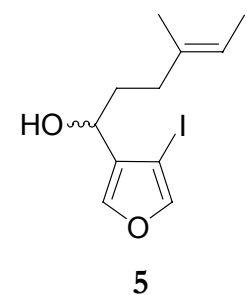

To a solution of iodide $3(13.6 \mathrm{~g}, 42.5 \mathrm{mmol})$ in $\mathrm{Et}_{2} \mathrm{O}(210 \mathrm{~mL})$ at $-78^{\circ} \mathrm{C}$ was added a solution of $n$-BuLi in hexanes $(17.0 \mathrm{~mL}, 2.5 \mathrm{M}, 43 \mathrm{mmol})$ over $2 \mathrm{~min}$. The yellow mixture was stirred for $15 \mathrm{~min}$, after which a solution of $(E)$-4-methylhex-4-enal $(4.14 \mathrm{~g}, 36.9 \mathrm{mmol})$ in $\mathrm{Et}_{2} \mathrm{O}(100 \mathrm{~mL})$ was added dropwise via cannula. After $20 \mathrm{~min}$ at $-78^{\circ} \mathrm{C}$, the reaction was quenched with a saturated $\mathrm{NH}_{4} \mathrm{Cl}$ solution $(200 \mathrm{~mL})$, diluted with ether, and washed with water $(150 \mathrm{~mL})$ and brine $(150 \mathrm{~mL})$. The organic layer was dried, filtered, and concentrated. The product was purified by column chromatography $(6 \%$ EtOAc in hexanes) to give $7.03 \mathrm{~g}(62 \%)$ of racemic 5 as a colorless oil: IR (film): 3368 (br), 2917, $2859 \mathrm{~cm}^{-1} ;{ }^{1} \mathrm{H}$ NMR: $\delta 7.40(\mathrm{~d}, J=1.2 \mathrm{~Hz}, 1 \mathrm{H}), 7.34$ (s, $1 \mathrm{H}), 5.27$ (m, $1 \mathrm{H}), 4.54$ (m, $1 \mathrm{H}), 2.34-2.01$ (m, $3 \mathrm{H}), 1.99$ $1.78(\mathrm{~m}, 2 \mathrm{H}), 1.64$ (s, $3 \mathrm{H}), 1.59$ (d, $J=6.8 \mathrm{~Hz}, 3 \mathrm{H}) ;{ }^{13} \mathrm{C}$ NMR: $\delta$ 146.2, 140.2, 135.3, 130.5, 119.4, 67.8, 66.3, 35.9, 35.1, 15.9, 13.6; HRMS (EI+): $m / z(\mathrm{M}+)$ calcd for $\mathrm{C}_{11} \mathrm{H}_{15} \mathrm{IO}_{2}$ 306.0117; found 306.0111 .

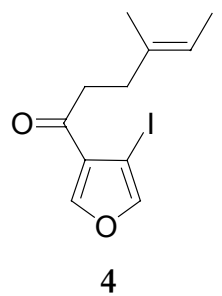

To a solution of alcohol $5(6.96 \mathrm{~g}, 22.7 \mathrm{mmol})$ in $\mathrm{CH}_{2} \mathrm{Cl}_{2}(115 \mathrm{~mL})$ at $0{ }^{\circ} \mathrm{C}$ was added DessMartin periodinane $(12.0 \mathrm{~g}, 28.3 \mathrm{mmol})$ in one portion. The solution was allowed to warm to rt over $2 \mathrm{~h}$ and then quenched with isopropanol. The solvent was removed, and the resulting white residue was redissolved in ether and washed successively with a 1:1 solution of $\mathrm{NaHCO}_{3} / \mathrm{Na}_{2} \mathrm{~S}_{2} \mathrm{O}_{3}(100 \mathrm{~mL})$, a saturated $\mathrm{NaHCO}_{3}$ solution $(100 \mathrm{~mL})$, water $(100 \mathrm{~mL})$, and brine $(100 \mathrm{~mL})$. The organic layer was dried, filtered, and concentrated. The product was purified by column chromatography ( $\%$ EtOAc in hexanes) to furnish $6.10 \mathrm{~g}(88 \%)$ of 4 as a colorless oil: IR (film): $3134,2975,2915,2859,1679 \mathrm{~cm}^{-1}$; ${ }^{1} \mathrm{H}$ NMR: $\delta$ $8.00(\mathrm{~d}, J=1.6 \mathrm{~Hz}, 1 \mathrm{H}), 7.48(\mathrm{~d}, J=1.2 \mathrm{~Hz}, 1 \mathrm{H}), 5.30-5.17(\mathrm{~m}, 1 \mathrm{H}), 2.85(\mathrm{~m}, 2 \mathrm{H}), 2.38(\mathrm{~m}, 2 \mathrm{H}), 1.63$ (s, $3 \mathrm{H}), 1.57(\mathrm{~d}, J=6.4 \mathrm{~Hz}, 3 \mathrm{H}) ;{ }^{13} \mathrm{C}$ NMR: $\delta 193.9,148.5,148.3,134.4,126.2,119.5,63.0,40.0,33.8$, 16.0, 13.6; HRMS (EI+): $m / z(M+)$ calcd for $\mathrm{C}_{11} \mathrm{H}_{13} \mathrm{IO}_{2}$ 303.9960; found 303.9954 . 


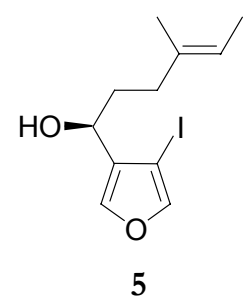

To a solution of (-)-B-chlorodiisopinocampheylborane (DIP-Cl, $665 \mathrm{mg}, 2.07 \mathrm{mmol}$ ) in THF (2 $\mathrm{mL})$ at $-20{ }^{\circ} \mathrm{C}$ was added a solution of ketone $4(570 \mathrm{mg}, 1.87 \mathrm{mmol})$ in THF $(1 \mathrm{~mL})$ via cannula. The reaction mixture was stirred at $-20{ }^{\circ} \mathrm{C}$ for $66 \mathrm{~h}$. The solvent was removed, the resulting residue was dissolved in ether, and neat diethanolamine $(0.40 \mathrm{~mL}, 4.2 \mathrm{mmol})$ was added. The mixture was stirred for another $12 \mathrm{~h}$ and then filtered through Celite. The product was purified by column chromatrography (4\% EtOAc to $5 \%$ EtOAc in hexanes) to afford $430 \mathrm{mg}(75 \%)$ of enantioenriched 5 as a colorless oil: $[\alpha]_{\mathrm{D}}=-$ $27.4\left(c=1.48, \mathrm{CHCl}_{3}\right)$. The enantiomeric excess was determined by chiral HPLC [Chiralpak $\mathrm{OD}^{\mathrm{TM}}$ column, $5 \% i$-PrOH in hexanes at $1.0 \mathrm{mLmin}^{-1} ; \mathrm{t}_{\mathrm{R}}($ major enantiomer $)=7.8 \mathrm{~min}, \mathrm{t}_{\mathrm{R}}($ minor enantiomer $)=$ $8.7 \mathrm{~min}]$ to be $94 \%$.

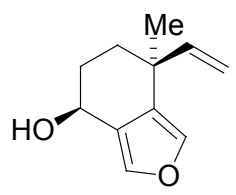

1



6

To a solution of alcohol 5 (2.90 g, $9.47 \mathrm{mmol})$ in $\mathrm{MeCN}(95 \mathrm{~mL})$ was added $\mathrm{H}_{2} \mathrm{O}(3.9 \mathrm{~mL}), \mathrm{Et}_{3} \mathrm{~N}$ (3.9 mL, $28 \mathrm{mmol}$ ), and tetrabutylammonium bromide (TBAB, $9.16 \mathrm{~g}, 28.4 \mathrm{mmol}$ ). The solution was purged with nitrogen for $15 \mathrm{~min}$, and then $\mathrm{Pd}(\mathrm{OAc})_{2}(105 \mathrm{mg}, 0.468 \mathrm{mmol})$ was quickly added. The reaction flask was placed in a preheated oil bath and stirred for $17 \mathrm{~h}$ at $75{ }^{\circ} \mathrm{C}$. The mixture was cooled, filtered through Celite with EtOAc washings, and concentrated. The resulting oil was triturated with $\mathrm{Et}_{2} \mathrm{O}$ and again filtered through Celite. The product was purified by column chromatography $(15 \%$ EtOAc in hexanes) to yield $1.40 \mathrm{~g}$ (83\%) of $\mathbf{1}$ and $\mathbf{6}$ as a 5.1:1 mixture of diastereomers: IR (film): 3345 (br), 2929 , $2865 \mathrm{~cm}^{-1}$; HRMS (EI+): $\mathrm{m} / z(\mathrm{M}+)$ calcd for $\mathrm{C}_{11} \mathrm{H}_{14} \mathrm{O}_{2}$ 178.0994; found 178.0989.

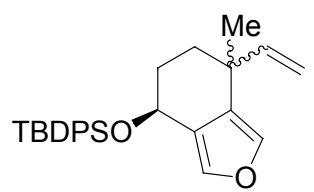

16

To a solution of alcohols 1 and $6(3.10 \mathrm{~g}, 17.4 \mathrm{mmol})$ in $\mathrm{CH}_{2} \mathrm{Cl}_{2}(175 \mathrm{~mL})$ was added imidazole (4.74 g, $69.6 \mathrm{mmol})$ and DMAP (20 mg, $0.16 \mathrm{mmol}$ ). This mixture was cooled to $0{ }^{\circ} \mathrm{C}$, and TBDPSCl 
$(6.0 \mathrm{~mL}, 23 \mathrm{mmol})$ was added dropwise via syringe. The solution was allowed to warm to rt for $12 \mathrm{~h}$, filtered through Celite with $\mathrm{CH}_{2} \mathrm{Cl}_{2}$ washings, and concentrated. The product was purified by column chromatography (2\% EtOAc in hexanes) to give $7.10 \mathrm{~g}$ (98\%) of $\mathbf{1 6}$ as a mixture of diastereomers: IR (film): 3071, 2956, 2931, $2857 \mathrm{~cm}^{-1}$; HRMS (EI+): $\mathrm{m} / z\left(\mathrm{M}+\right.$ ) calcd for $\mathrm{C}_{27} \mathrm{H}_{32} \mathrm{O}_{2} \mathrm{Si} 416.2172$; found 416.2167.

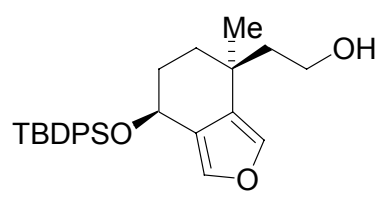

7

To a solution of 9-BBN dimer $(435 \mathrm{mg}, 1.78 \mathrm{mmol})$ in THF $(7.4 \mathrm{~mL})$ was added a solution of alkene $16(742 \mathrm{mg}, 1.78 \mathrm{mmol})$ in THF $(7.4 \mathrm{~mL})$ dropwise via cannula. The flask containing the alkene was rinsed with an additional $1 \mathrm{~mL}$ THF. The mixture was heated at reflux for $4 \mathrm{~h}$ and then cooled to 0 ${ }^{\circ} \mathrm{C}$. EtOH $(2.5 \mathrm{~mL})$ was slowly added. A $3 \mathrm{M}$ aqueous $\mathrm{NaOH}$ solution $(1.8 \mathrm{~mL})$ and a $30 \%$ aqueous $\mathrm{H}_{2} \mathrm{O}_{2}$ solution $(1.8 \mathrm{~mL})$ were then added. After $10 \mathrm{~min}$ at $0{ }^{\circ} \mathrm{C}$, the solution was allowed to warm to $\mathrm{rt}$ over $3 \mathrm{~h}$. The mixture was poured into water $(50 \mathrm{~mL})$ and extracted with ether $(3 \mathrm{x} 100 \mathrm{~mL})$. The combined organic extracts were washed once with brine $(30 \mathrm{~mL})$, dried, filtered, and concentrated. The product was purified by column chromatography (20\% EtOAc in hexanes) to yield $623 \mathrm{mg}(81 \%)$ of 7 as a colorless oil: IR (film): 3350 (br), 3070, 2932, $2857 \mathrm{~cm}^{-1}$; ${ }^{1} \mathrm{H}$ NMR: $\delta 7.67$ (m, $\left.4 \mathrm{H}\right), 7.46-7.30$ (m, $6 \mathrm{H}$ ), $7.12(\mathrm{~s}, 1 \mathrm{H}), 6.76(\mathrm{~s}, 1 \mathrm{H}), 4.80(\mathrm{~m}, 1 \mathrm{H}), 3.74(\mathrm{~m}, 2 \mathrm{H}), 2.03(\mathrm{~m}, 1 \mathrm{H}), 1.88-1.76(\mathrm{~m}, 1 \mathrm{H}), 1.74-1.60$ (m, $2 \mathrm{H}), 1.55-1.39$ (m, $2 \mathrm{H}), 1.30(\mathrm{~m}, 1 \mathrm{H}), 1.13$ (s, $3 \mathrm{H}), 1.05$ (s, $9 \mathrm{H}) ;{ }^{13} \mathrm{C}$ NMR: $\delta 139.4,137.5,136.1$, 136.1, 134.5, 134.2, 130.0, 129.9, 127.8, 127.8, 124.8, 63.8, 60.2, 45.7, 32.5, 31.8, 30.3, 30.1, 27.2, 19.4; HRMS (EI+): $m / z(M+)$ calcd for $\mathrm{C}_{27} \mathrm{H}_{34} \mathrm{O}_{3} \mathrm{Si} 434.2277$; found 434.2279.

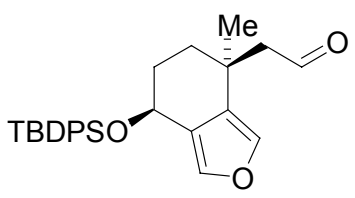

17

Dry $\mathrm{CH}_{2} \mathrm{Cl}_{2}(7.5 \mathrm{~mL})$ was added to a solution of oxalyl chloride in $\mathrm{CH}_{2} \mathrm{Cl}_{2}(1.7 \mathrm{~mL}, 2.0 \mathrm{M}, 3.4$ $\mathrm{mmol})$ at $-78^{\circ} \mathrm{C}$. DMSO $(0.48 \mathrm{~mL}, 6.8 \mathrm{mmol})$ was added to this solution dropwise via syringe. After 30 min at $-78{ }^{\circ} \mathrm{C}$, a solution of alcohol $7(492 \mathrm{mg}, 1.13 \mathrm{mmol})$ in $\mathrm{CH}_{2} \mathrm{Cl}_{2}(7.5 \mathrm{~mL})$ was added via cannula. The flask containing the alcohol was rinsed with an additional $1 \mathrm{~mL} \mathrm{CH}_{2} \mathrm{Cl}_{2}$. The reaction mixture was stirred at $-78{ }^{\circ} \mathrm{C}$ for $1 \mathrm{~h}$, and $\mathrm{Et}_{3} \mathrm{~N}(1.4 \mathrm{~mL}, 10 \mathrm{mmol})$ was added dropwise via syringe. The mixture was allowed to warm to rt over $2 \mathrm{~h}$, then quenched with water, poured into water $(50 \mathrm{~mL})$ and a saturated 
$\mathrm{NH}_{4} \mathrm{Cl}$ solution $(50 \mathrm{~mL})$, and extracted with $\mathrm{CH}_{2} \mathrm{Cl}_{2}(3 \times 50 \mathrm{~mL})$. The combined organic extracts were dried, filtered, and concentrated. The product was purified by column chromatography $(10 \%$ EtOAc in hexanes) to furnish $445 \mathrm{mg}$ (91\%) of $\mathbf{1 7}$ as a colorless oil: IR (film): 3018, 2932, 2858, $1719 \mathrm{~cm}^{-1} ;{ }^{1} \mathrm{H}$ NMR: $\delta 9.79(\mathrm{t}, J=2.8 \mathrm{~Hz}, 1 \mathrm{H}), 7.69(\mathrm{~m}, 4 \mathrm{H}), 7.50-7.35(\mathrm{~m}, 6 \mathrm{H}), 7.19(\mathrm{~d}, J=1.6 \mathrm{~Hz}, 1 \mathrm{H}), 6.79(\mathrm{~m}, 1$ H), $4.86(\mathrm{~m}, 1 \mathrm{H}), 2.60$ (t, $J=2.8 \mathrm{~Hz}, 2 \mathrm{H}), 2.12(\mathrm{~m}, 1 \mathrm{H}), 1.91-1.72(\mathrm{~m}, 2 \mathrm{H}), 1.48(\mathrm{~m}, 1 \mathrm{H}), 1.28$ (s, 3 H), 1.07 (s, $9 \mathrm{H}) ;{ }^{13} \mathrm{C}$ NMR: $\delta$ 203.3, 139.8, 137.8, 136.1, 136.1, 134.4, 134.1, 129.9, 129.0, 127.9, 127.8, 124.6, 63.5, 55.8, 33.0, 31.7, 30.0, 29.9, 27.1, 19.4; HRMS (EI+): $m / z(M+)$ calcd for $\mathrm{C}_{27} \mathrm{H}_{32} \mathrm{O}_{3} \mathrm{Si}$ 432.2121; found 432.2118 .

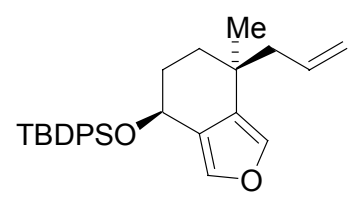

18

To a solution of methyltriphenylphosphonium bromide (1.32 g, $3.70 \mathrm{mmol})$ in THF $(12.4 \mathrm{~mL})$ was added a solution of $n$-BuLi in hexanes $(1.3 \mathrm{~mL}, 2.4 \mathrm{M}, 3.1 \mathrm{mmol})$ at $0{ }^{\circ} \mathrm{C}$ dropwise via syringe. After $1 \mathrm{~h}$ at $0{ }^{\circ} \mathrm{C}$, a solution of aldehyde $17(445 \mathrm{mg}, 1.03 \mathrm{mmol})$ in THF (6.8 mL) was added via cannula. The flask containing the aldehyde was rinsed twice with $1 \mathrm{~mL}$ THF. After $5 \mathrm{~min}$ the mixture was allowed to warm to $\mathrm{rt}$ and then quenched with water after $1 \mathrm{~h}$. The solution was poured into water $(50 \mathrm{~mL})$ and extracted with ether $(3 \times 50 \mathrm{~mL})$. The combined organic extracts were washed once with brine $(30 \mathrm{~mL})$, dried, filtered, and concentrated. The product was purified by column chromatography ( $2 \%$ EtOAc in hexanes) to afford $422 \mathrm{mg}$ (95\%) of $\mathbf{1 8}$ as a colorless oil: IR (film): 3071, 2956, 2931, 2857, $2360 \mathrm{~cm}^{-1}$; ${ }^{1} \mathrm{H}$ NMR: $\delta$ 7.79-7.69 (m, $\left.4 \mathrm{H}\right), 7.52-7.35(\mathrm{~m}, 6 \mathrm{H}), 7.16(\mathrm{~d}, J=1.6 \mathrm{~Hz}, 1 \mathrm{H}), 6.85(\mathrm{~m}, 1 \mathrm{H}), 5.87(\mathrm{~m}, 1$ H), 5.15-5.06 (m, 2 H), 4.88 (m, 1 H), 2.34 (m, 2 H), 2.01 (m, 1 H), 1.93-1.82 (m, 1 H), 1.79-1.70 (m, 1 $\mathrm{H}), 1.32(\mathrm{~m}, 1 \mathrm{H}), 1.15(\mathrm{~s}, 3 \mathrm{H}), 1.12(\mathrm{~s}, 9 \mathrm{H}) ;{ }^{13} \mathrm{C}$ NMR: $\delta 139.1,137.5,136.1,136.1,135.6,134.7$, $134.4,130.3,129.8,127.8,127.8,125.1,117.7,64.4,47.7,32.8,32.8,30.1,29.3,27.2$, 19.5; HRMS $(\mathrm{EI}+): m / z(\mathrm{M}+)$ calcd for $\mathrm{C}_{28} \mathrm{H}_{34} \mathrm{O}_{2} \mathrm{Si} 430.2328$; found 430.2327 .

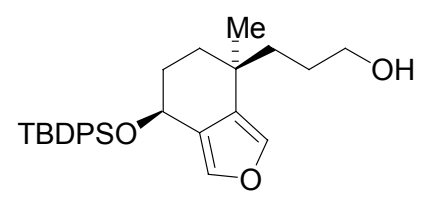

19

To a solution of 9-BBN dimer $(259 \mathrm{mg}, 1.06 \mathrm{mmol})$ in THF $(4 \mathrm{~mL})$ was added a solution of alkene 18 (416 mg, $0.966 \mathrm{mmol})$ in THF (4 mL) dropwise via cannula. The flask containing the alkene was rinsed twice with $1 \mathrm{~mL}$ THF. After $5 \mathrm{~h}$ at $\mathrm{rt}$, the mixture was cooled to $0{ }^{\circ} \mathrm{C}$, and $\mathrm{EtOH}(1.4 \mathrm{~mL})$ was 
slowly added. A $3 \mathrm{M}$ aqueous $\mathrm{NaOH}$ solution $(1 \mathrm{~mL})$ and a $30 \%$ aqueous $\mathrm{H}_{2} \mathrm{O}_{2}$ solution $(1 \mathrm{~mL})$ were then added. After $10 \mathrm{~min}$ at $0{ }^{\circ} \mathrm{C}$, the solution was allowed to warm to $\mathrm{rt}$ over $1 \mathrm{~h}$. The mixture was poured into water $(50 \mathrm{~mL})$ and extracted with ether $(3 \times 50 \mathrm{~mL})$. The combined organic extracts were washed once with brine $(30 \mathrm{~mL})$, dried, filtered, and concentrated. The product was purified by column chromatography (20\% EtOAc in hexanes) to yield $398 \mathrm{mg}$ (92\%) of 19 as a colorless oil: IR (film): 3350 (br), 3070, 2933, $2857 \mathrm{~cm}^{-1}$; ${ }^{1} \mathrm{H}$ NMR: $\delta 7.78-7.67$ (m, $\left.4 \mathrm{H}\right), 7.50-7.36(\mathrm{~m}, 6 \mathrm{H}), 7.15(\mathrm{~d}, J=1.6 \mathrm{~Hz}, 1 \mathrm{H})$, $6.84(\mathrm{~m}, 1 \mathrm{H}), 4.87(\mathrm{~m}, 1 \mathrm{H}), 3.69-3.63(\mathrm{~m}, 2 \mathrm{H}), 2.00(\mathrm{~m}, 1 \mathrm{H}), 1.93-1.83(\mathrm{~m}, 1 \mathrm{H}), 1.79-1.58(\mathrm{~m}, 6 \mathrm{H})$, $1.34(\mathrm{~m}, 1 \mathrm{H}), 1.16(\mathrm{~s}, 3 \mathrm{H}), 1.11(\mathrm{~s}, 9 \mathrm{H}) ;{ }^{13} \mathrm{C}$ NMR: $\delta 139.2,137.3,136.1,136.1,134.6,134.3,130.4$, $129.8,129.8,127.8,127.7,125.1,64.2,63.7,39.3,32.5,32.4,30.1,29.6,28.2,27.1$, 19.4; HRMS (EI+): $\mathrm{m} / \mathrm{z}(\mathrm{M}+)$ calcd for $\mathrm{C}_{28} \mathrm{H}_{36} \mathrm{O}_{3} \mathrm{Si} 448.2434$; found 448.2427 .



Dry $\mathrm{CH}_{2} \mathrm{Cl}_{2}(5.3 \mathrm{~mL})$ was added to a solution of oxalyl chloride in $\mathrm{CH}_{2} \mathrm{Cl}_{2}(1.2 \mathrm{~mL}, 2.0 \mathrm{M}, 2.4$ $\mathrm{mmol})$ at $-78^{\circ} \mathrm{C}$. DMSO $(0.34 \mathrm{~mL}, 4.8 \mathrm{mmol})$ was added to this solution dropwise via syringe. After 30 min at $-78{ }^{\circ} \mathrm{C}$, a solution of alcohol $19(354 \mathrm{mg}, 0.789 \mathrm{mmol})$ in $\mathrm{CH}_{2} \mathrm{Cl}_{2}(5.3 \mathrm{~mL})$ was added via cannula. The flask containing the alcohol was rinsed twice with $1 \mathrm{~mL} \mathrm{CH} \mathrm{Cl}_{2}$. The reaction mixture was stirred at $-78{ }^{\circ} \mathrm{C}$ for $1 \mathrm{~h}$, and $\mathrm{Et}_{3} \mathrm{~N}(1.0 \mathrm{~mL}, 7.2 \mathrm{mmol})$ was added dropwise via syringe. The mixture was allowed to warm to $\mathrm{rt}$ over $2 \mathrm{~h}$, then quenched with water, poured into water $(50 \mathrm{~mL})$ and a saturated $\mathrm{NH}_{4} \mathrm{Cl}$ solution $(50 \mathrm{~mL})$, and extracted with $\mathrm{CH}_{2} \mathrm{Cl}_{2}(3 \times 50 \mathrm{~mL})$. The combined organic extracts were dried, filtered, and concentrated. The product was filtered through a plug of silica (20\% EtOAc in hexanes) to furnish 11 as a colorless oil, which was immediately taken on into the next step: IR (film): 3071, 2932, 2858, $1725 \mathrm{~cm}^{-1}$; ${ }^{1} \mathrm{H}$ NMR: $\delta 9.81(\mathrm{~m}, 1 \mathrm{H}), 7.76-7.65$ (m, $\left.4 \mathrm{H}\right), 7.50-7.36(\mathrm{~m}, 6 \mathrm{H}), 7.13(\mathrm{~d}, J=1.2 \mathrm{~Hz}, 1$ H), 6.77 (m, $1 \mathrm{H}), 4.85(\mathrm{~m}, 1 \mathrm{H}), 2.62-2.41(\mathrm{~m}, 2 \mathrm{H}), 1.99$ (m, $1 \mathrm{H}), 1.93-1.82(\mathrm{~m}, 3 \mathrm{H}), 1.78-1.67$ (m, 1 H), $1.33(\mathrm{~m}, 1 \mathrm{H}), 1.15(\mathrm{~s}, 3 \mathrm{H}), 1.09(\mathrm{~s}, 9 \mathrm{H})$. To a solution of aldehyde 11 in MeCN (7.8 mL) was added ethyl diazoacetate $(0.22 \mathrm{~mL}, 1.6 \mathrm{mmol})$ followed by 1,8-diazabicyclo[5.4.0]undec-7-ene (DBU, $22 \mu \mathrm{L}$, $0.15 \mathrm{mmol})$ dropwise via syringe. The mixture was stirred at $\mathrm{rt}$ for $15 \mathrm{~h}$, then poured into water $(50 \mathrm{~mL})$ and extracted with ether $(3 \times 50 \mathrm{~mL})$. The combined organic extracts were washed once with brine $(30$ $\mathrm{mL})$, dried, filtered, and concentrated. The product was purified by column chromatography (20\% EtOAc in hexanes) to afford $336 \mathrm{mg}$ (76\%) of 12 as a colorless oil: IR (film): 3441 (br), 3071, 2930, 2857, 2094, $1681 \mathrm{~cm}^{-1}$; ${ }^{1} \mathrm{H}$ NMR: $\delta 7.71(\mathrm{~m}, 4 \mathrm{H}), 7.50-7.35$ (m, $\left.6 \mathrm{H}\right), 7.13(\mathrm{~s}, 1 \mathrm{H}), 6.79(\mathrm{~s}, 1 \mathrm{H}), 4.84(\mathrm{~m}, 1 \mathrm{H}), 4.67$ (m, 1 H), 4.27 (q, $J=7.2$ Hz, 2 H), 2.84 (br s, 1 H), 2.08-1.94 (m, 1 H), 1.92-1.49 (m, 6 H), 1.38-1.26 (m, 
$4 \mathrm{H}), 1.15$ (s, $3 \mathrm{H}), 1.08$ (s, $9 \mathrm{H}) ;{ }^{13} \mathrm{C}$ NMR: $\delta$ 166.8, 139.3, 137.3, 136.1, 136.1, 134.6, 134.3, 130.1, $129.9,129.8,127.8,127.7,124.9,67.5,67.4,63.9,63.8,61.2,39.2,39.0,32.5,32.1,31.9,30.0,29.7$, 29.5, 27.1, 19.4, 14.7; HRMS (FAB+): $m / z$ (MLi+) calcd for $\mathrm{C}_{32} \mathrm{H}_{40} \mathrm{~N}_{2} \mathrm{O}_{5} \mathrm{SiLi}$ 567.2867; found 567.2876.

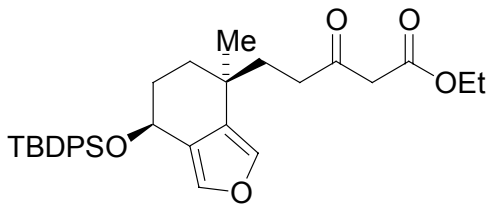

20

To a solution of alcohol $12(336 \mathrm{mg}, 0.559 \mathrm{mmol})$ in $\mathrm{CH}_{2} \mathrm{Cl}_{2}(12 \mathrm{~mL})$ was added $\mathrm{Rh}_{2}(\mathrm{OAc})_{4}(26$ $\mathrm{mg}, 0.060 \mathrm{~mol}$ ). The reaction mixture bubbled. After $30 \mathrm{~min}$ the solution was concentrated, and the crude material was filtered through a plug of silica (30\% EtOAc in hexanes) to give $302 \mathrm{mg}(95 \%)$ of 20 as a colorless oil: IR (film): 3070, 2932, 2857, 1744, $1719 \mathrm{~cm}^{-1} ;{ }^{1} \mathrm{H} \mathrm{NMR}^{1}: \delta 7.76-7.64$ (m, $\left.4 \mathrm{H}\right), 7.50$ 7.35 (m, $6 \mathrm{H}), 7.12$ (d, J=1.2 Hz, $1 \mathrm{H}), 6.76(\mathrm{~m}, 1 \mathrm{H}), 4.85$ (m, $1 \mathrm{H}), 4.21$ (q, $J=7.2 \mathrm{~Hz}, 2 \mathrm{H}), 3.44(\mathrm{~s}, 2$ H), 2.62 (m, 2 H), 2.09-1.82 (m, 4 H), 1.78-1.67 (m, 1 H), 1.36-1.23 (m, 4 H), 1.15 (s, 3 H), 1.10 (s, 9 H); ${ }^{13} \mathrm{C}$ NMR: $\delta$ 203.1, 167.3, 139.4, 137.4, 136.1, 136.0, 134.4, 134.2, 129.9, 129.2, 127.8, 127.7, 124.9, 63.4, 61.5, 49.5, 39.2, 36.2, 32.3, 31.5, 30.0, 30.0, 27.1, 19.4, 14.3; HRMS (FAB+): $m / z(M L i+)$ calcd for $\mathrm{C}_{32} \mathrm{H}_{40} \mathrm{O}_{5} \mathrm{SiLi}$ 539.2805; found 539.2815.



13

To a solution of ketoester $20(392 \mathrm{mg}, 0.736 \mathrm{mmol})$ in $\mathrm{MeCN}(7.4 \mathrm{~mL})$ at $0{ }^{\circ} \mathrm{C}$ was added $\mathrm{Et}_{3} \mathrm{~N}$ (0.31 mL, $2.2 \mathrm{mmol}$ ) followed by 4-acetamidobenzenesulfonyl azide (354 mg, $1.47 \mathrm{mmol})$. After $10 \mathrm{~min}$ at $0{ }^{\circ} \mathrm{C}$, the solution was allowed to warm to $\mathrm{rt}$ over $4 \mathrm{~h}$. The mixture was poured into water $(50 \mathrm{~mL})$ and extracted with ether $(3 \times 50 \mathrm{~mL})$. The combined organic extracts were washed once with brine $(30 \mathrm{~mL})$, dried, filtered, and concentrated. The product was purified by column chromatography $(10 \%$ EtOAc in hexanes) to afford $377 \mathrm{mg}$ (92\%) of $\mathbf{1 3}$ as a colorless oil: IR (film): 3071, 2932, 2857, 2134, 1713, 1658 $\mathrm{cm}^{-1}$; ${ }^{1} \mathrm{H}$ NMR: $\delta$ 7.77-7.65 (m, $\left.4 \mathrm{H}\right), 7.49-7.35$ (m, $\left.6 \mathrm{H}\right), 7.19(\mathrm{~d}, J=1.2 \mathrm{~Hz}, 1 \mathrm{H}), 6.84(\mathrm{~m}, 1 \mathrm{H}), 4.83$ $(\mathrm{m}, 1 \mathrm{H}), 4.30(\mathrm{q}, J=7.2 \mathrm{~Hz}, 2 \mathrm{H}), 2.95$ (m, $2 \mathrm{H}), 2.03-1.83(\mathrm{~m}, 4 \mathrm{H}), 1.79-1.68$ (m, $1 \mathrm{H}), 1.40-1.29$ (m, 4 H), 1.16 (s, $3 \mathrm{H}), 1.08$ (s, $9 \mathrm{H}) ;{ }^{13} \mathrm{C}$ NMR: $\delta 193.3,161.5,139.3,137.5,136.1,136.1,134.6,134.3,129.8$,

\footnotetext{
${ }^{1}$ The NMR spectra of this compound indicate that about $15 \%$ of the $\beta$-ketoester exists in the enol form: ${ }^{1} \mathrm{H}$ NMR: $12.20(\mathrm{~s}, 0.17 \mathrm{H}), 5.03(\mathrm{~s}, 0.18 \mathrm{H})$.
} 
$129.8,127.8,127.7,125.0,64.2,61.5,37.0,36.4,32.6,32.5,30.1,29.2,27.2,19.4$, 19.1, 14.6; HRMS $(\mathrm{FAB}+): m / z(\mathrm{MLi}+)$ calcd for $\mathrm{C}_{32} \mathrm{H}_{38} \mathrm{~N}_{2} \mathrm{O}_{5} \mathrm{SiLi}$ 565.2710; found 565.2717.



To a solution of $\mathrm{Rh}_{2}(\mathrm{OAc})_{4}(10 \mathrm{mg}, 0.023 \mathrm{~mol})$ in $\mathrm{CH}_{2} \mathrm{Cl}_{2}(40 \mathrm{~mL})$ was added a solution of diazo compound 13 (44.0 mg, $0.0787 \mathrm{mmol})$ in $\mathrm{CH}_{2} \mathrm{Cl}_{2}(2 \mathrm{~mL})$ dropwise via syringe. The flask containing the diazo compound was rinsed twice with $1 \mathrm{~mL} \mathrm{CH}_{2} \mathrm{Cl}_{2}$. The solution was stirred for $4 \mathrm{~h}$ at $\mathrm{rt}$ and then concentrated. The product was purified by column chromatography (20\% EtOAc in hexanes) to yield $20.4 \mathrm{mg}$ (50\%) of 15 as a colorless oil: IR (film): 2932, 2857, 2254, 1729, $1688 \mathrm{~cm}^{-1}$; ${ }^{1} \mathrm{H}$ NMR: $\delta 9.57$ (s, $1 \mathrm{H}), 8.00(\mathrm{~s}, 1 \mathrm{H}), 7.75-7.68(\mathrm{~m}, 2 \mathrm{H}), 7.60-7.52(\mathrm{~m}, 2 \mathrm{H}), 7.49-7.30(\mathrm{~m}, 6 \mathrm{H}), 4.66(\mathrm{~m}, 1 \mathrm{H}), 4.33$ (q, $J=$ $7.2 \mathrm{~Hz}, 2 \mathrm{H}), 2.75-2.65$ (m, $1 \mathrm{H}), 2.61-2.49$ (m, $1 \mathrm{H}), 2.27$ (m, $1 \mathrm{H}), 1.96$ (m, $1 \mathrm{H}), 1.83-1.72(\mathrm{~m}, 2 \mathrm{H})$, 1.63-1.50 (m, $2 \mathrm{H}), 1.36$ (t, $J=7.2 \mathrm{~Hz}, 3 \mathrm{H}), 1.06$ (s, $3 \mathrm{H}), 1.00(\mathrm{~s}, 9 \mathrm{H}) ;{ }^{13} \mathrm{C}$ NMR: $\delta 200.2,191.0,164.3$, 155.1, 143.9, 138.1, 136.2, 136.1, 134.0, 133.5, 130.0, 130.0, 127.8, 127.8, 62.2, 62.0, 39.6, 38.7, 34.1, 29.7, 27.3, 27.2, 19.5, 14.4; HRMS (EI+): $m / z(\mathrm{M}+)$ calcd for $\mathrm{C}_{32} \mathrm{H}_{38} \mathrm{O}_{5} \mathrm{Si} 530.2489$; found 530.2494. 


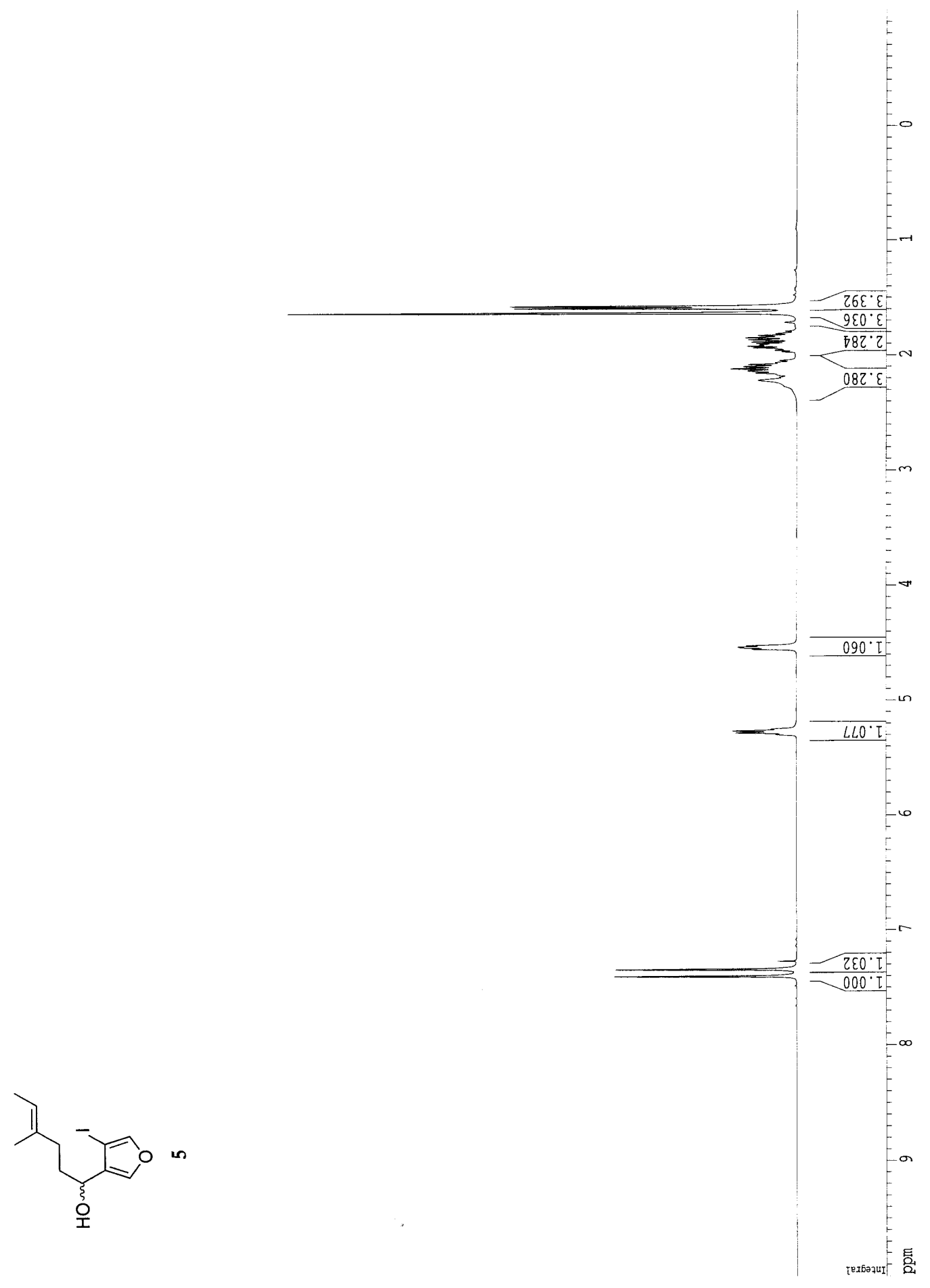




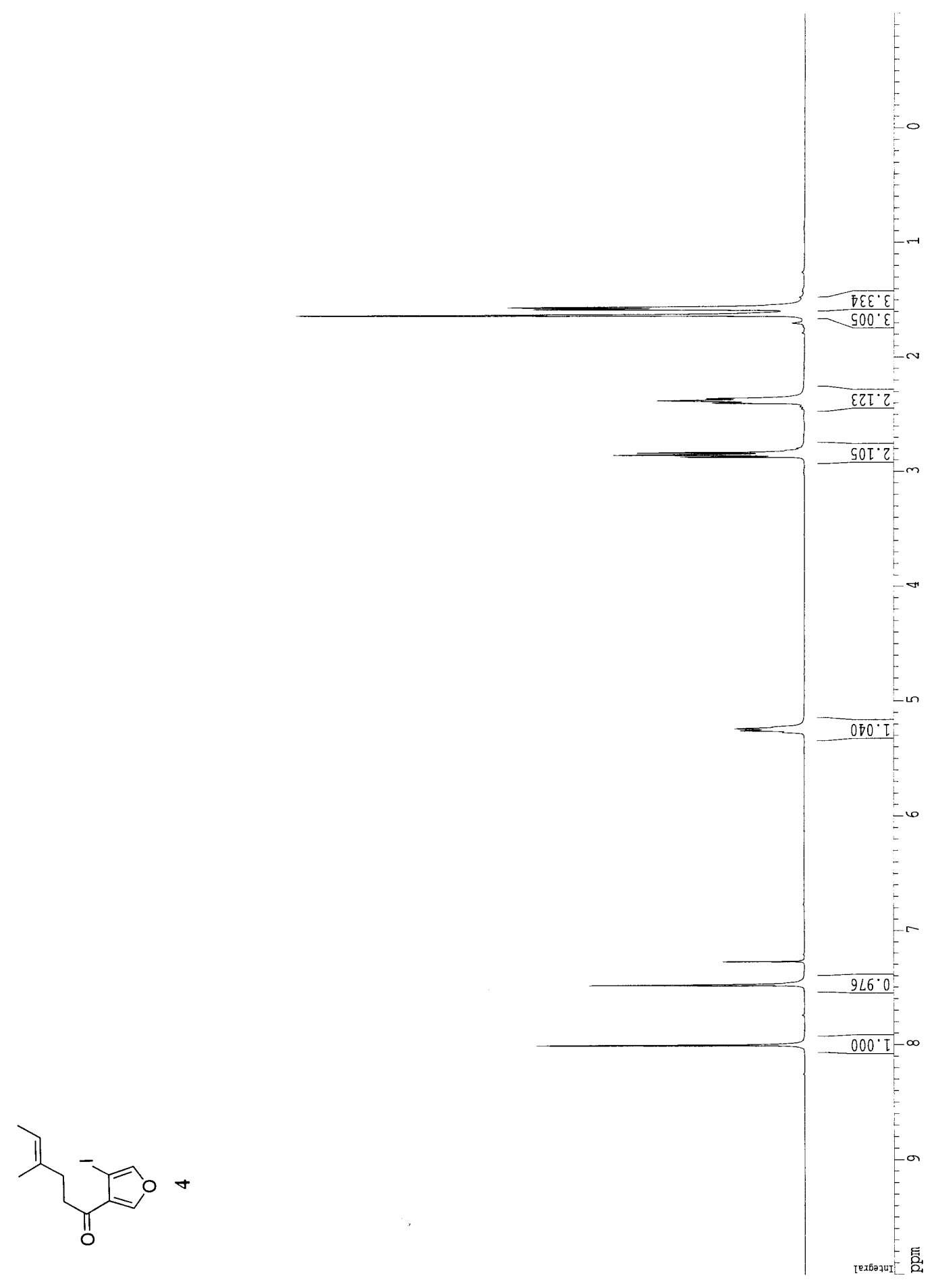




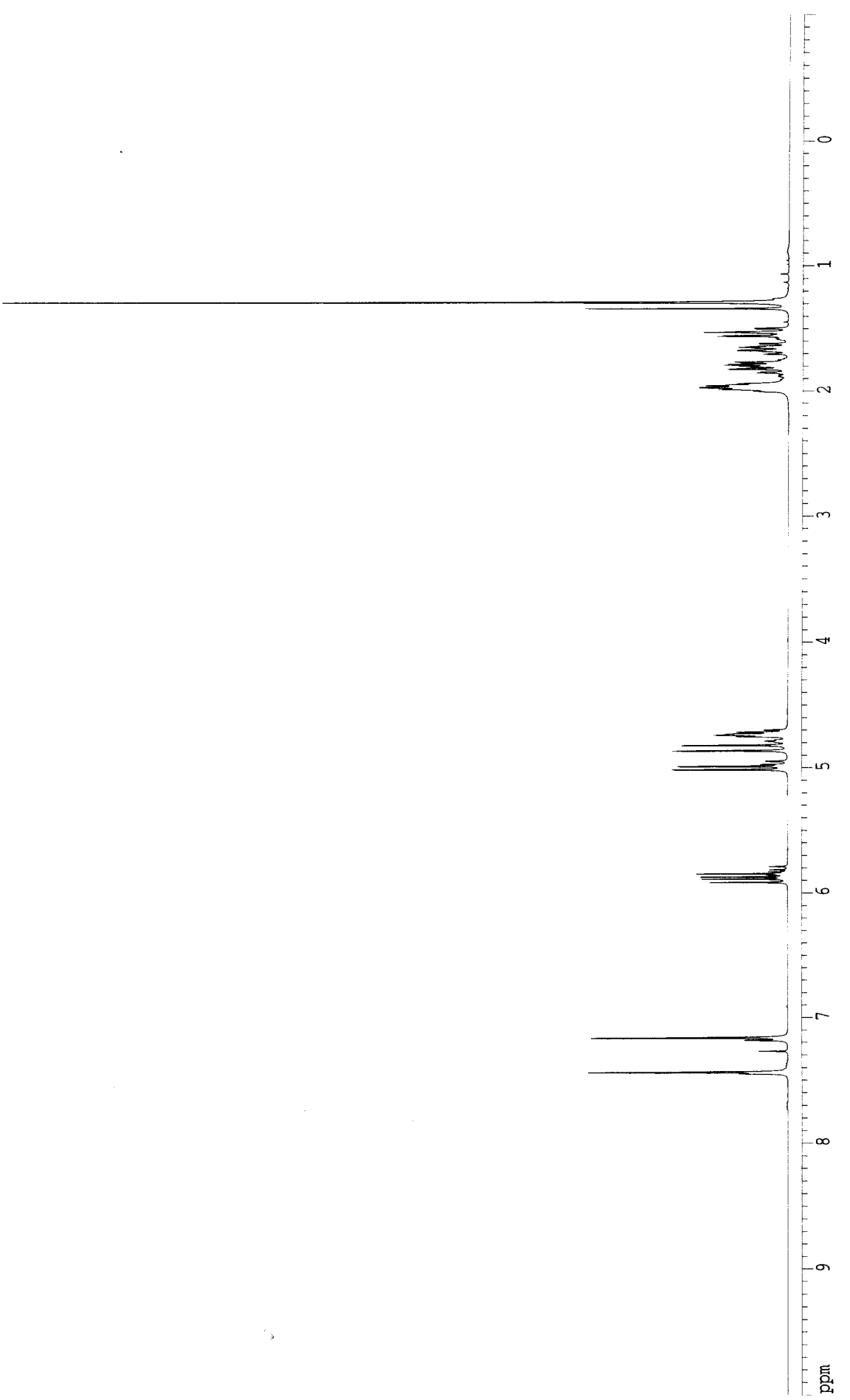









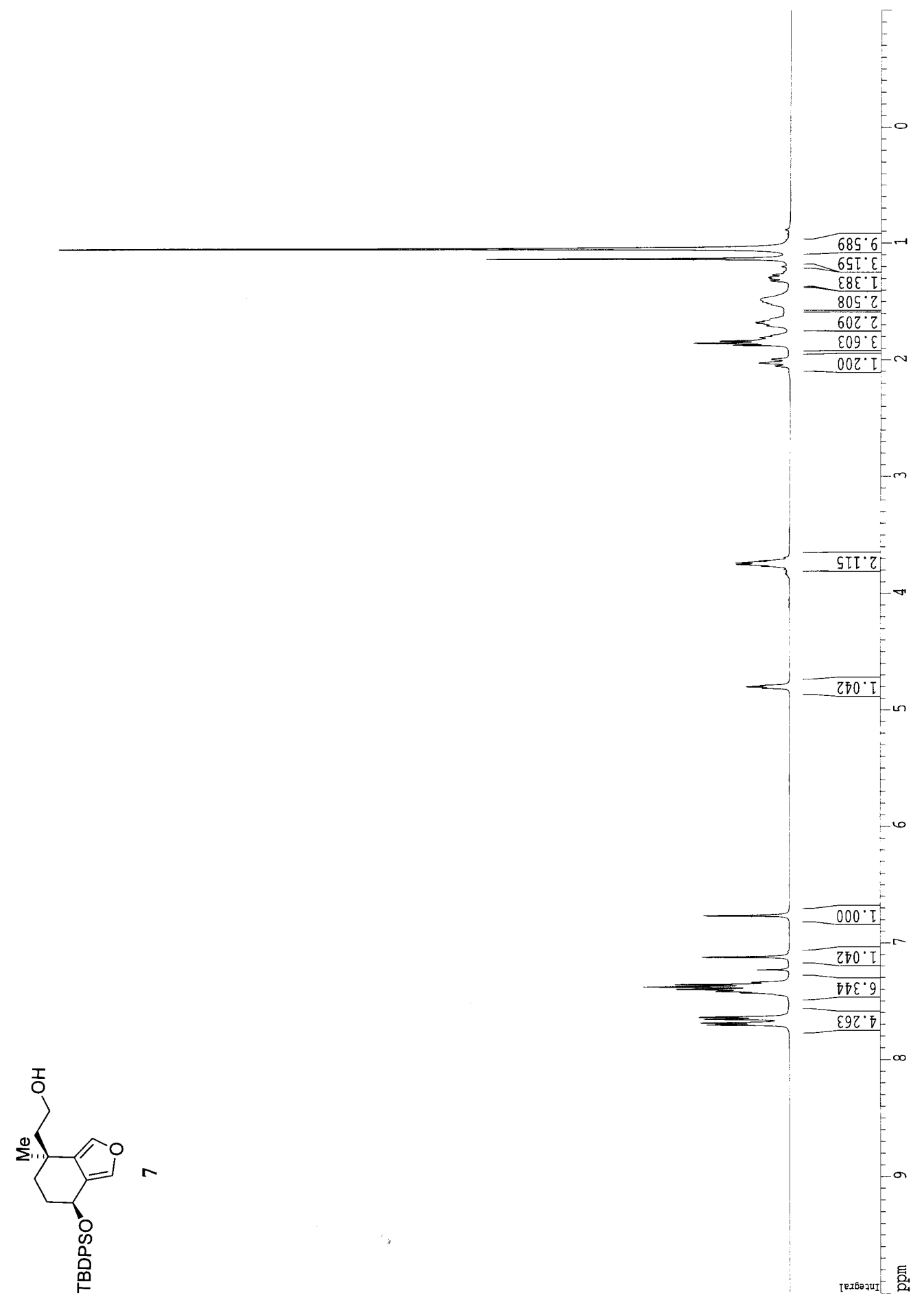




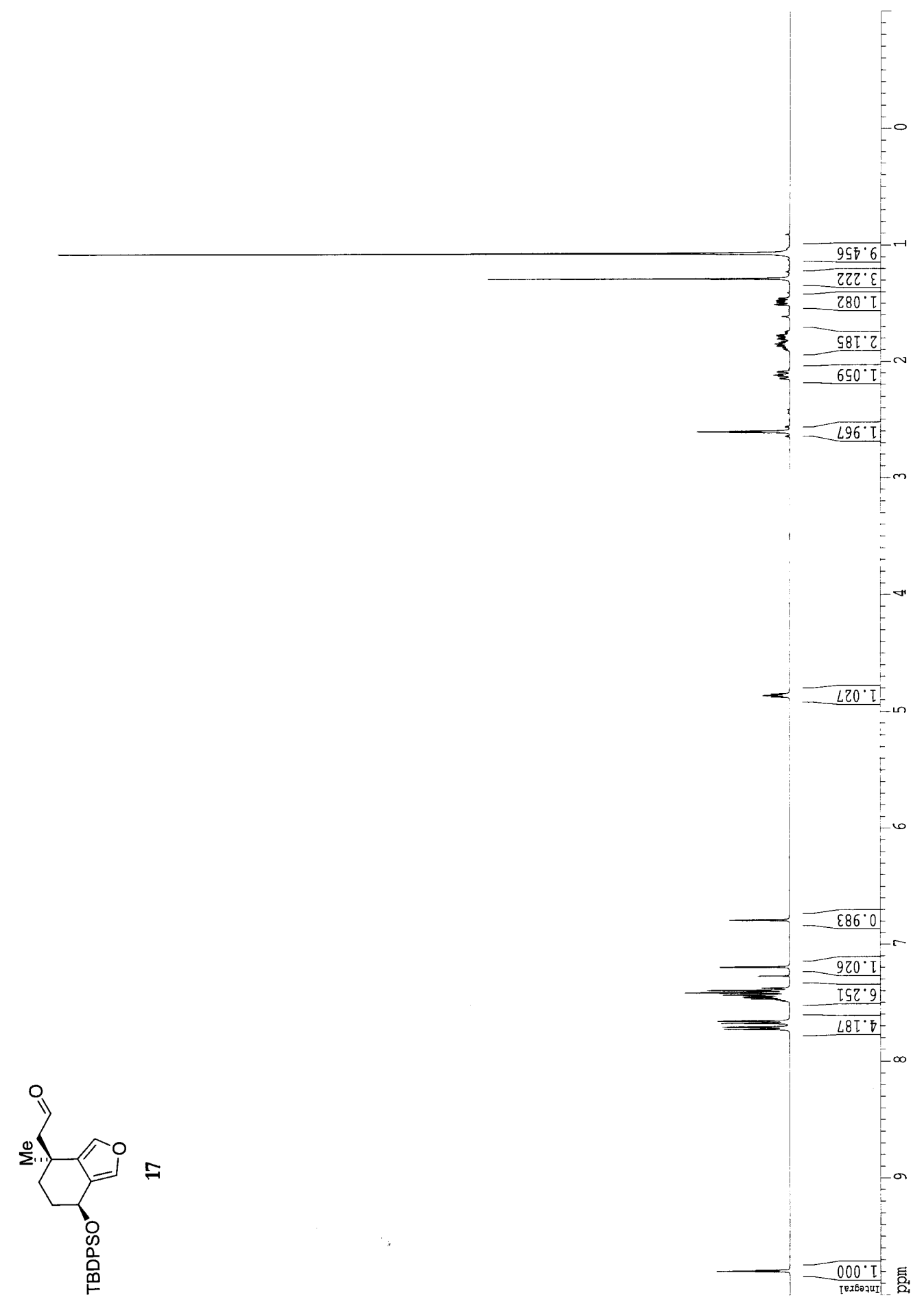




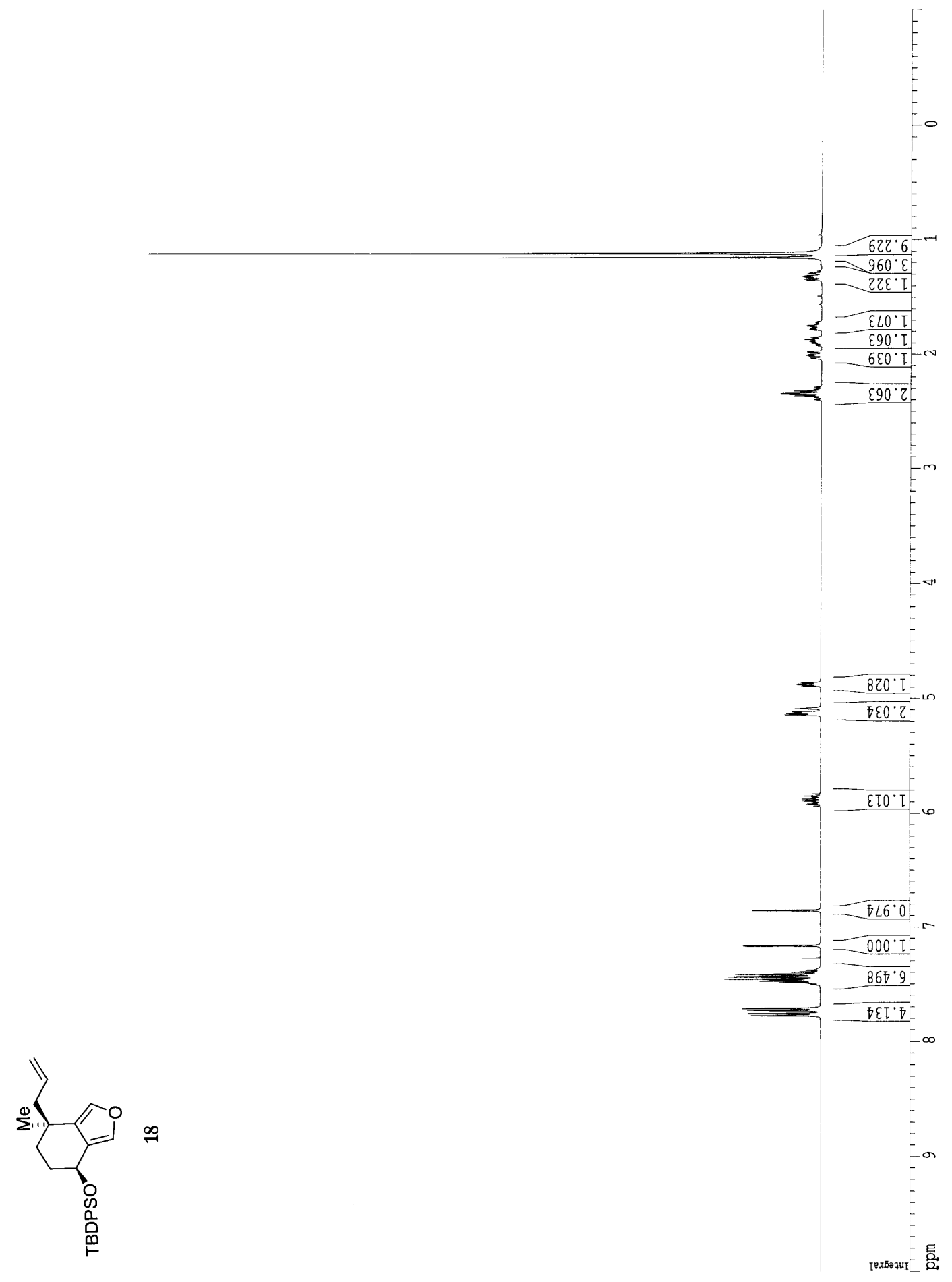




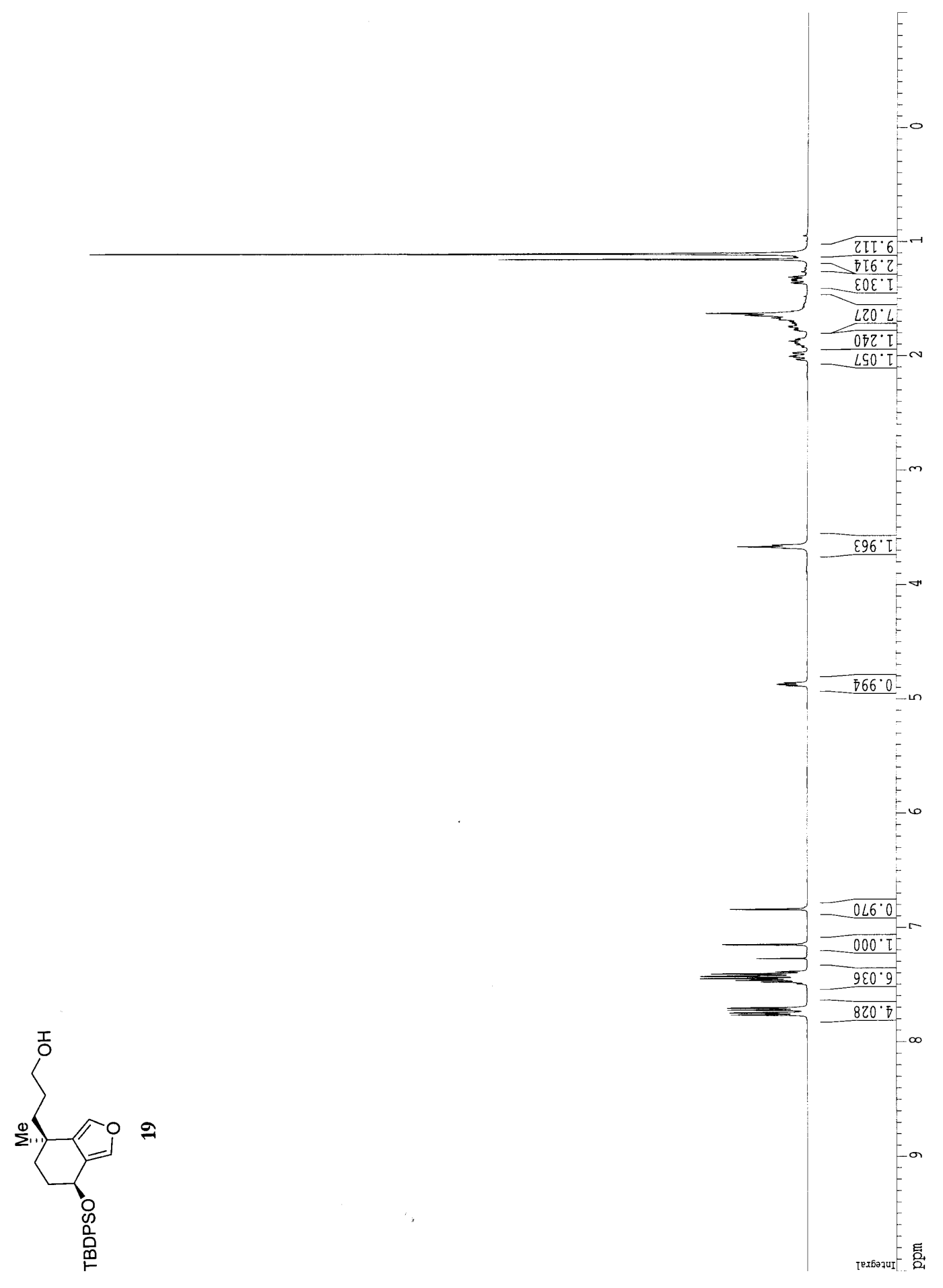




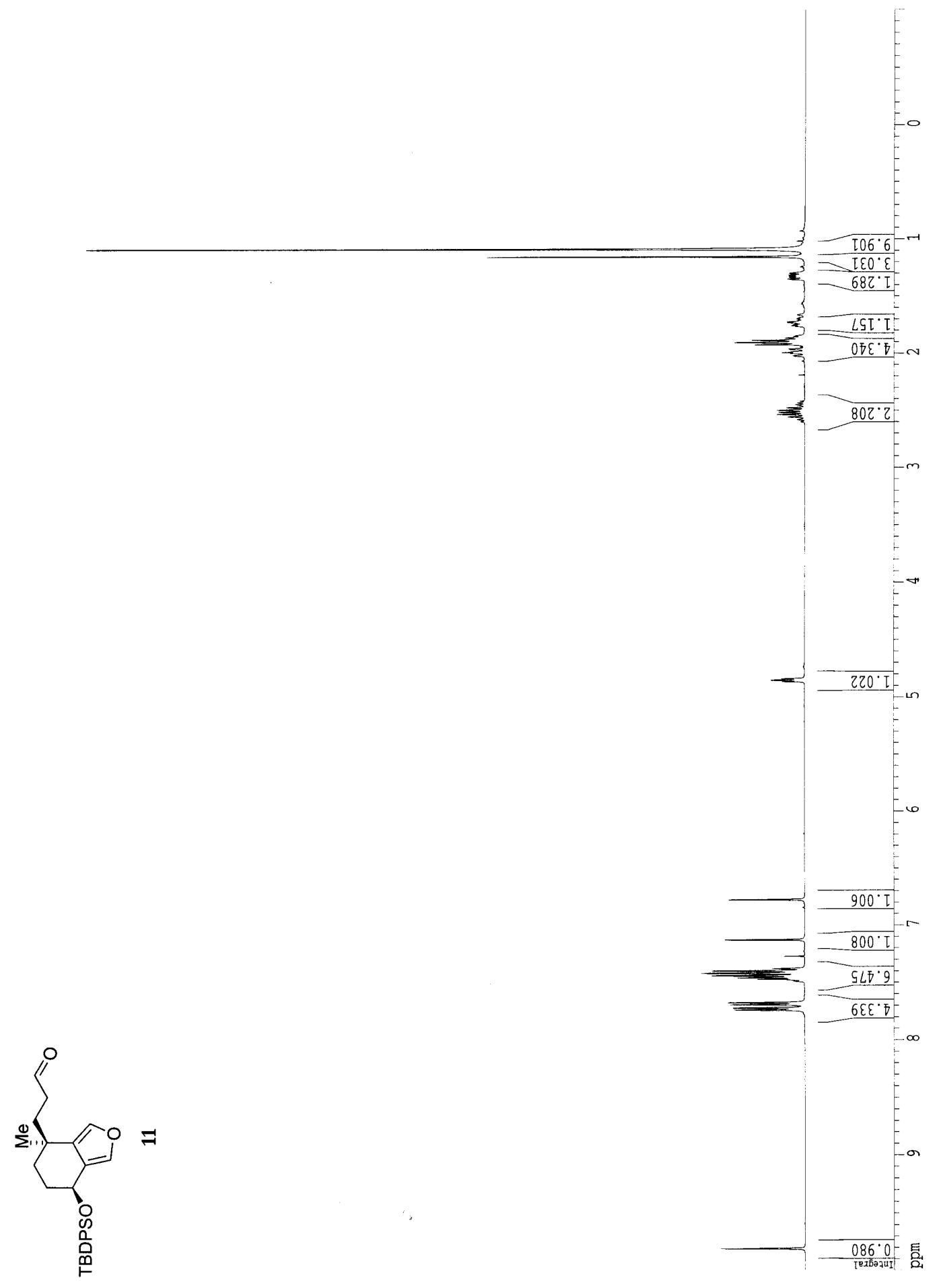




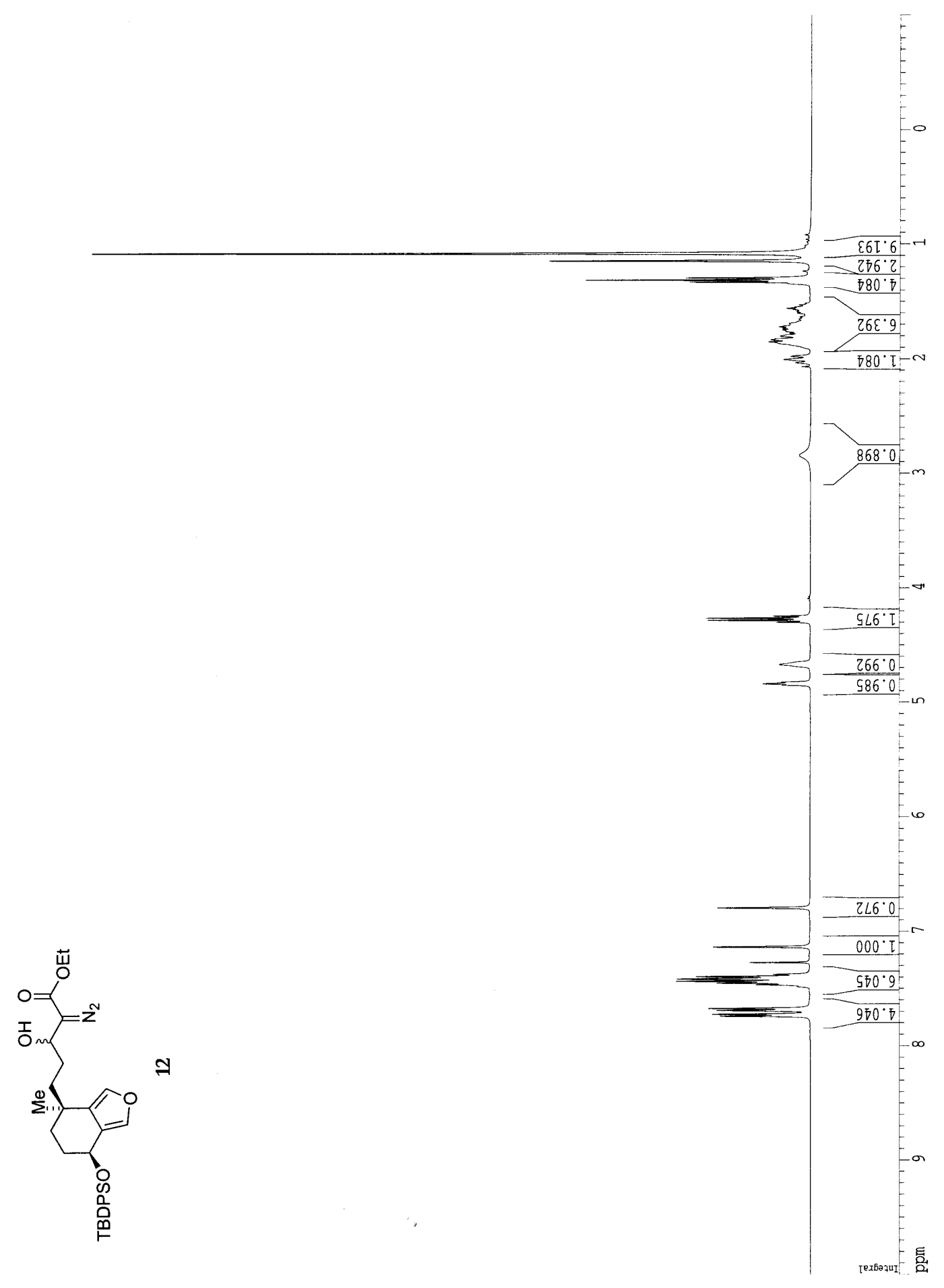









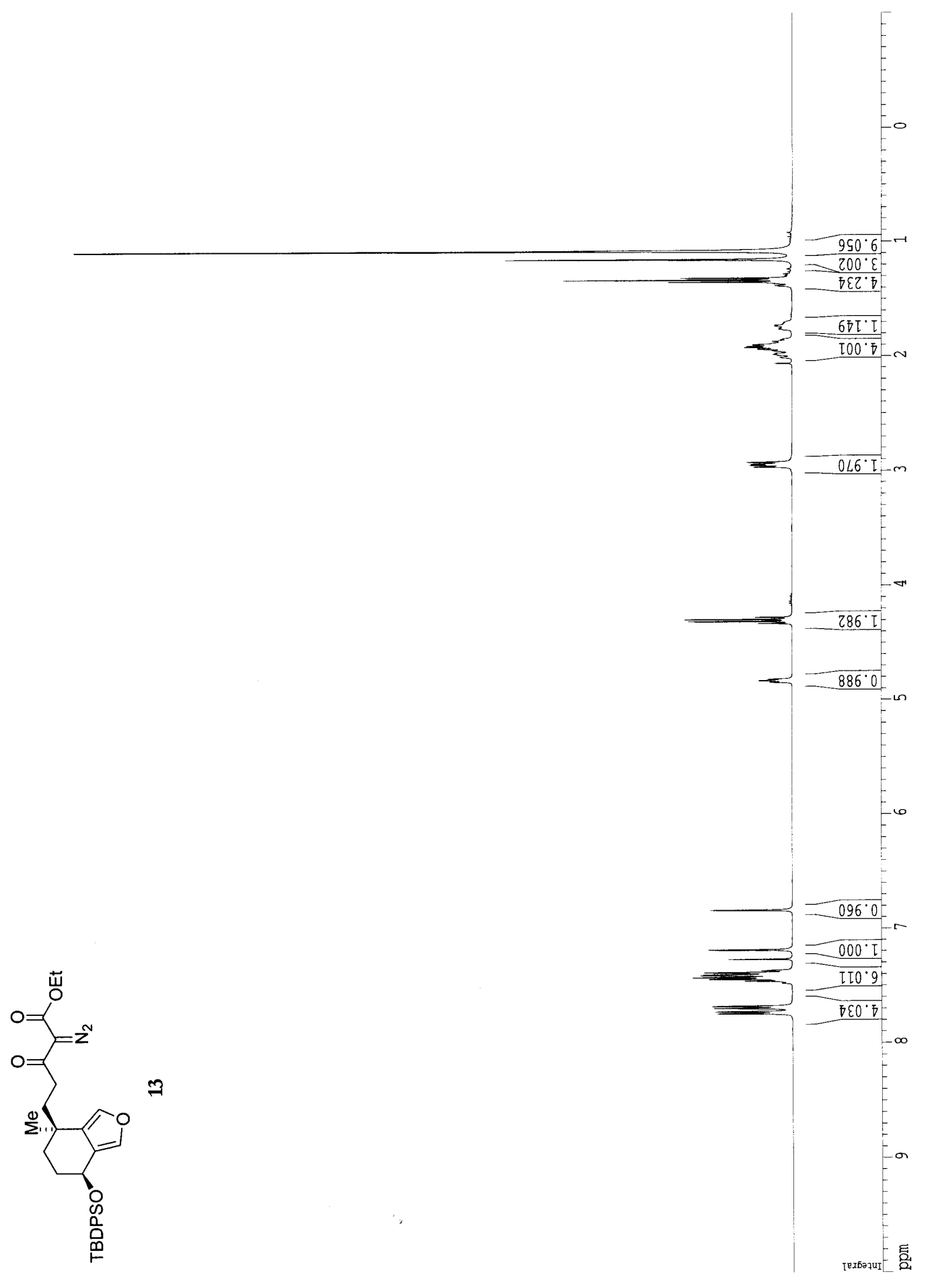




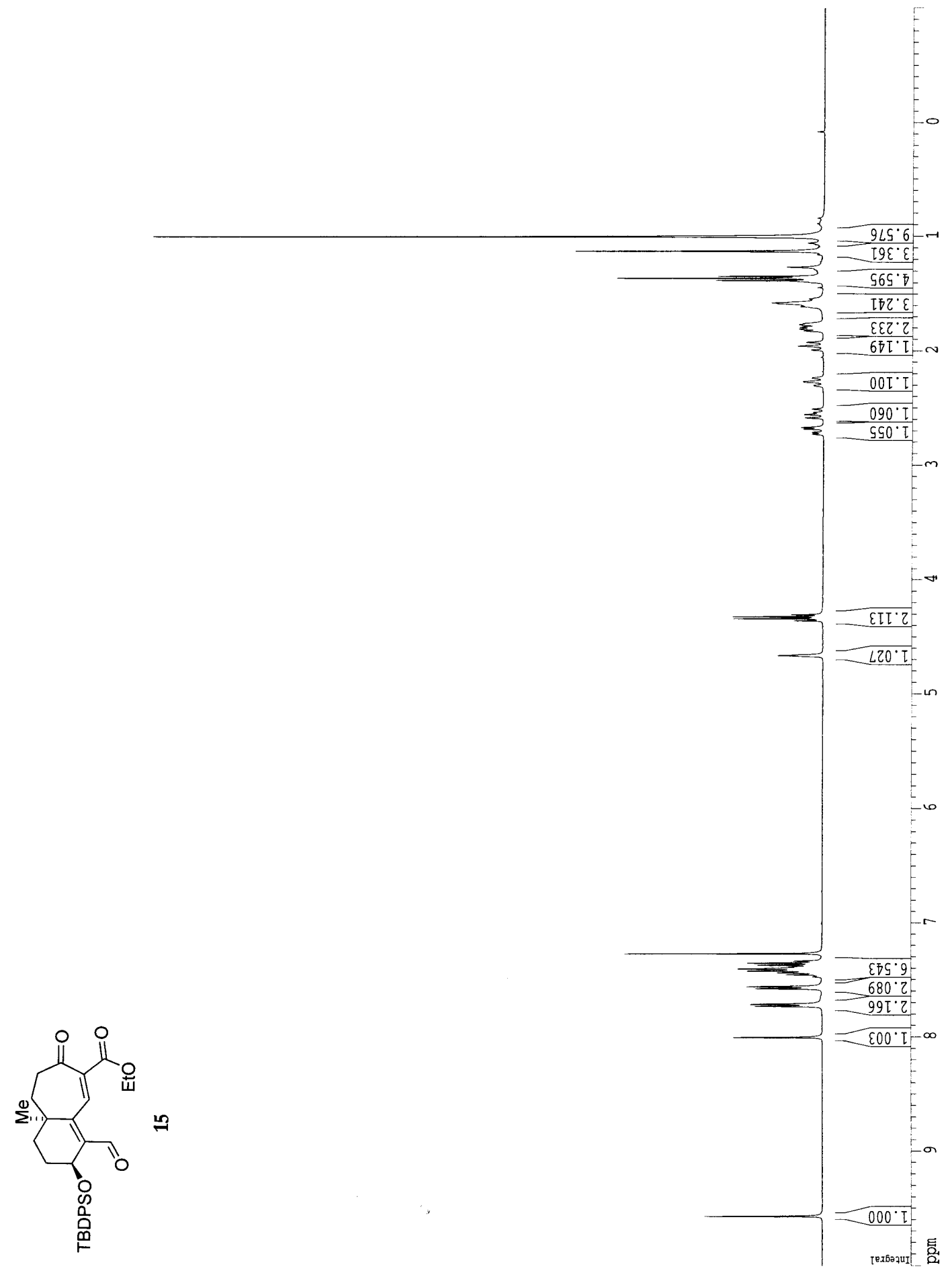


A. Crystal Data

Empirical Formula

Formula Weight

Crystal Color, Habit

Crystal Dimensions

Crystal System

Lattice Type

Lattice Parameters

Space Group

$\mathrm{Z}$ value

$\mathrm{D}_{\text {calc }}$

$\mathrm{F}_{000}$

$\mu(\mathrm{MoK} \alpha)$

Diffractometer

Radiation

Detector Position

Exposure Time

Scan Type

$2 \theta_{\max }$

No. of Reflections Measured

Corrections

\author{
$\mathrm{C}_{11} \mathrm{O}_{3} \mathrm{H}_{16}$ \\ 196.25 \\ colorless, blocklike \\ $0.10 \times 0.18 \times 0.19 \mathrm{~mm}$ \\ orthorhombic \\ Primitive \\ $\mathrm{a}=7.898(1) \AA$ \\ $\mathrm{b}=14.181(2) \AA$ \\ $\mathrm{c}=17.856(2) \AA$ \\ $\mathrm{V}=1999.8(4) \AA^{3}$ \\ Pbca $(\# 61)$ \\ 8 \\ $1.304 \mathrm{~g} / \mathrm{cm}^{3}$ \\ 848.00 \\ $0.93 \mathrm{~cm}^{-1}$
}

B. Intensity Measurements



C. Structure Solution and Refinement

Structure Solution
Refinement
Function Minimized
Least Squares Weights
p-factor
Anomalous Dispersion
No. Observations $(I>3.00 \sigma(\mathrm{I}))$

Direct Methods

Full-matrix least-squares

$\Sigma w(|F o|-|F c|)^{2}$

$w=\frac{1}{\sigma^{2}(F o)}=\left[\sigma_{c}^{2}(F o)+\frac{p^{2}}{4} F o^{2}\right]^{-1}$

0.0300

All non-hydrogen atoms

1105 
No. Variables

Reflection/Parameter Ratio

Residuals: R; Rw; Rall

Goodness of Fit Indicator

Max Shift/Error in Final Cycle

Maximum peak in Final Diff. Map

Minimum peak in Final Diff. Map
133

8.31

$0.044 ; 0.050 ; 0.078$

1.74

0.00

$0.22 e^{-/ \AA^{3}}$

$-0.23 e^{-} / \AA^{3}$ 